\title{
The Northern Great Basin: A Region of Continual Change
}

\author{
By Tony Svejcar
}

\section{On the Ground}

- The Great Basin of the United States has experienced large climatic fluctuations over the past 10,000 years. Lake Bonneville (the remnant of which is the Great Salt Lake) at one time covered almost 20,000 square miles, which is about the size of Lake Michigan. The fact that the region is internally drained amplifies the effects of climatic shifts on the Great Basin environment.

- Euro-American exploration also had dramatic effects on the Great Basin environment. Some of the early exploration involved intentional destruction of resources (decimating beaver populations) to make the region less appealing to potential competitors. The removal of beaver would have affected riparian areas of the Great Basin as early as the 1820 s.

- The American settlement period was also fairly destructive. The various Homestead Acts were not designed with the Great Basin in mind and the mix of homesteaded (private) and un-homesteaded (public) land created a chaotic setting where the first person to arrive used the forage. This situation persisted until the Taylor Grazing Act of 1934.

- There are clearly reasons for concern over the expansion of annual grasses and extensive wildfires. However, recent planning efforts associated with improving habitat for greater sage-grouse provide examples where science and management have been integrated, and there is a much needed focus on evaluating the success of management practices. The outcome of these efforts should be increased accountability for those involved in rangeland management in the northern Great Basin.

Keywords: historical change, homesteads, wildfire, shrub steppe.

Rangelands 37(3):114-118

doi: $10.1016 /$ j.rala.2015.03.002

(C) 2015 The Society for Range Management

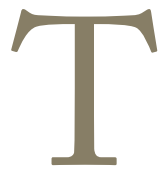

he Great Basin of the western United States has been written off as an ecological disaster by some. But out of challenges come opportunities. In this article, I provide a brief history of the region, and point to some of the opportunities and challenges. The Great Basin can be defined several ways, but regardless of definition, it covers much of Nevada, western Utah, southern Idaho, southeastern Oregon, and parts of eastern California. The most common definition of the Great Basin is the hydrologic definition - the region where none of the flowing water travels to the ocean. Many people are amazed to learn that a region this size can be totally unconnected to the oceans. The Sierras to the west and the Rockies to the east play a major role in shaping the Great Basin. This "internal drainage" is one reason the area has experienced such dramatic changes over the past 12,000 years; a change in climate influences not just the vegetation, but also the surface area of water.

Another way to characterize the Great Basin is based on "floristics" or dominant vegetation types. This definition generally involves the area dominated by shrub/grass plant communities (often called shrub steppe). The dominant shrubs are often species of sagebrush (Artemisia sp.) or saltbush (Artiplex sp.). This definition tends to be applied to a broader area than does the hydrologic definition. For this discussion, I focus on the northern Great Basin.

\section{Fairly Distant History}

Although I don't want to dwell too much on the distant past, it is necessary to go back an Epoch or two to understand the Great Basin.*, 1 During the Miocene and Pliocene Epochs (about 24 to 1.8 million years ago), there was massive volcanic activity, uplifting of mountains, huge dams and associated

\footnotetext{
Much of the historical information cited in this article comes from the remarkably well-documented Humbolt River Chronology, Nevada Water Basin Information and Chronology Series, published by the Nevada Division of Water Resources. The series has two parts relevant to this article: Part II - PreTwentieth Century. Available at: http://water.nv.gov/mapping/chronologies/ humboldt/hrc-pt2.pdf. Accessed 21 August 2014; and Part III - Twentieth and Twenty-First Centuries Available at: http://water.nv.gov/mapping/ chronologies/humboldt/hrc-pt3.pdf. Accessed 21 August 2014.
} 
lakes, and serious regional warming. By the end of the Pliocene, the current geologic landscape was pretty well set. However, climate and biology would still undergo major changes. The Pleistocene Epoch (The Last Ice Age 1.8 million to 11,700 years ago) created a much different environment than what we see today. The Cascades and Sierras had significant glaciers, and the cool relatively wet conditions created huge inland lakes. At this point, there was no drainage to the ocean in the hydrologic Great Basin. So when the climate became wetter and cooler (lower evaporation), the stage was set for the pluvial lakes of the Great Basin.

The Great Basin in general was characterized by a lot of surface water and many marshes during this period. The two largest lakes were Lake Lahontan to the west and Lake Bonneville to the east. The Great Salt Lake is a remnant of Lake Bonneville, which at its peak was almost 20,000 square miles (about the size of Lake Michigan) and more than 1,000 feet deep. The highest shoreline of this ancient lake was 5,100 feet and is referred to as the Bonneville Bench. To the west, Lake Lahontan covered more than 8,500 square miles in northwestern Nevada, northeastern California, and southern Oregon. The maximum depth was about 900 feet at present day Pyramid Lake. At its peak, this Ice Age lake was equal to $8 \%$ of Nevada's surface area. During the early Pleistocene, the shoreline was about 4,590 feet above sea level and by late Pleistocene the level was 4,380 feet above sea level. The gradual warming at the end of the Pleistocene (about 10,000 years ago) spelled the beginning of the end for all that lakefront property in the Great Basin.

Evidence suggests that humans entered the region about 12,000 years ago, and they made use of the lakefront property. Much of the early human activity was associated with the lakes and marshes of the Great Basin. In that respect, human habits have not really changed that much. We still tend to congregate around lakes and rivers. When European explorers first arrived (late 1700s in the south, early 1800s in the north), the region was inhabited by a collection of Great Basin tribes, including the Paiute, Ute, and Shoshone. The Native American population may have played a major role in shaping landscape-level vegetation patterns. There is substantial evidence that the early inhabitants of the Great Basin were active in using fire to manipulate vegetation and thus influenced the observations of early Euro-American explorers and settlers. ${ }^{2}$

\section{Recorded History}

Some parts of the historical record are better than others, but at least there are bits and pieces that can be woven together. There are some broad periods or themes that can be developed. The first period involves early exploration and fur trapping. The early Spanish explorers visited parts of the southern Great Basin as they traveled in the southwestern United States and southern California. By the early 1800s, fur trappers with the British Hudson Bay Company made numerous trips across southeastern Oregon and into parts of Idaho and northern Nevada. Peter Skeen Ogden led a series of exploratory trips to the area in the late 1820s. The British
Hudson Bay Company employed a "scorch and burn" strategy when it came to beaver trapping. They knew the beaver represented an economic resource for the region that would draw Spanish and American fur companies. In an attempt to reduce the interest in the region, they intentionally overtrapped populations of beavers. ${ }^{3}$ This activity probably had a huge effect on riparian areas and wetlands.

The next phase of activity revolved around the mineral resources of the region. Mining had a boom period in parts of the Great Basin; and with mining came the need for infrastructure, including transportation. Many of the "Forty-Niners" traveling to California in search of gold crossed through the Humboldt River Valley in northern Nevada. The late 1840s and early 1850 s was a period of unprecedented westward migration and set the region up for the settlement that was to follow. Before the mining boom, much of the European settlement in the far west was restricted to the western parts of Washington, Oregon, and California. There were many derogatory comments about the Great Basin from those traveling through this part of the country. The one that might sum it up the best: "God-forsaken country that never was designed to be the habitation of a Christian or civilized man." ${ }^{4}$ So the folks from places with lots of water, green pastures, and forests were not too impressed with geologic and biological diversity of the Great Basin.

But with time, the mining activity and grazing potential of the northern Great Basin did attract settlers. As crop acreages increased in more productive areas, livestock producers were left to find new areas for their animals. Certainly, the mining activity was very important to the economic base of the region, but another boom was to follow - the demand for fresh meat. Part of the demand was in fact driven by the influx of miners; but there was also demand in the eastern United States. There was an enormous amount of speculation in livestock especially in the northern Great Plains - with money flowing in from the eastern United States and even Europe. As with most economic bubbles, the return on investment was just too good to pass up. There were cattle and sheep on Great Basin rangeland but also large numbers of beasts of burden-horses and oxen. Livestock also provided "horsepower" during this period of history; however, that started to change with the railroad. By October 1, 1868, the Central Pacific Railroad reached Winnemucca, Nevada, from the west and opened for business. In May 1869, the Central Pacific and Union Pacific Railroads met at Promontory Point, Utah. At that point, it was possible to transport products into and out of the northern Great Basin to either the east or west.

Everything appeared to be in place for the big livestock boom - land seemed abundant, venture capital was flowing in, demand was good, and transportation was available. But the open-range operations that depended on land that was not homesteaded and was still in federal ownership had limited ability to adjust to harsh weather conditions. Even those livestock operations with mostly deeded (private) land were not prepared for either harsh winters or extended drought. It was the tough winters that would burst this particular bubble. First, on the northern Plains, the winter of 1886-1887 caused about half of the livestock in Wyoming and Montana to perish. The rangeland was severely overstocked and raising hay for winter 
feeding had not yet caught on. Further west, the winter of 1889-1890 proved to be the rough one. In northern Nevada, drifting snow and $-40^{\circ} \mathrm{F}$ temperatures resulted in severe livestock losses. One cattle company west of Elko, Nevada reported 98\% winter death losses. The situation in both areas was compounded by the dry year preceding the hard winter. Weather caused a destocking of the rangeland and the nature of the livestock industry would change. In the future, more long-term operations would have base property (deeded land) where hay would be raised as winter feed to complement rangeland grazed during the spring, summer, and fall months.

So again, the northern Great Basin went through a period of turmoil, in this case where man and nature were clearly at odds over how things should turn out. More turmoil would come, some of which was a result of the limited understanding of the region by those running the country. There were a variety of ways settlers could acquire land in the region. The various Homestead Acts were intended to put most federal lands in private ownership. The original Homestead Act was signed by President Lincoln in 1862 and allowed settlers to acquire 160 acres for only the cost of filing a claim. ${ }^{5}$ Not many families could survive on 160 acres in the northern Great Basin. In the Great Basin, the land around water was homesteaded and unclaimed dryer sites were grazed on a first-come basis. The unclaimed areas created the disputes referred to as the "range wars." People with deeded property in an area may have felt they had priority in use of these unclaimed lands; but in reality whoever got there first, used the forage. There were many roaming sheep bands that used forage before the "locals" had a chance. More than a few Hollywood films resulted from this little segment of history.

The Enlarged Homestead Act of 1909 allowed for 320 acres and the Stock-Raising Homestead Act of 1916 allowed 640 acres. ${ }^{5}$ Major John Wesley Powell was sent to evaluate this region of the country. He reported in 1878 that a farm unit should be not less than 2,560 acres and should have irrigatable lands and small streams. ${ }^{6}$ The US Congress thought Powell's

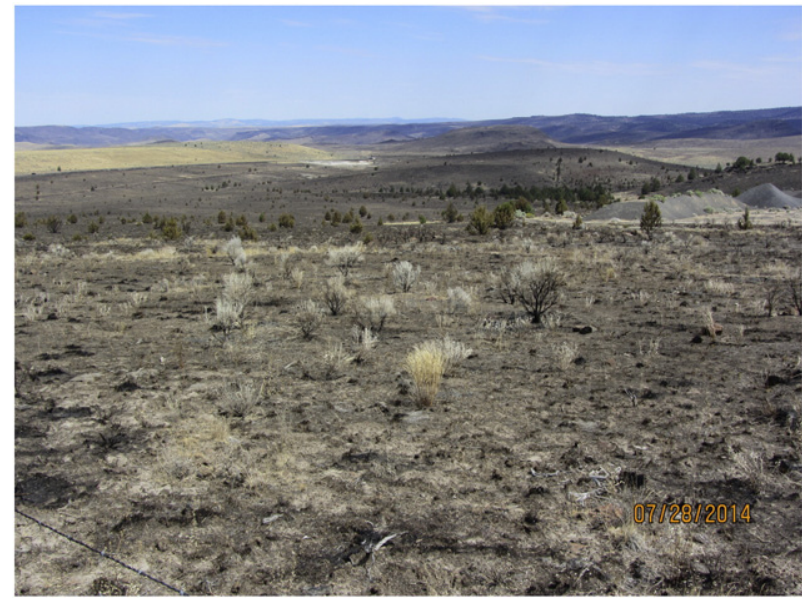

Figure 1. Buzzard Complex fire, which burned about 400,000 acres in southeastern Oregon in 2014. At one time a fire this size would have been extraordinary, but large rangeland fires have become rather common in the northern Great Basin. suggestions were out of line. Congressmen and senators did not jump on a plane and go have a field hearing back then, so most people in Washington, DC had no idea what the Great Basin was like; many still don't. Given that much of the land could not be homesteaded, it remained in the public domain.

There was no management of the unclaimed public lands until the federal Taylor Grazing Act was passed in 1934. So there was a long period of unrestricted, heavy grazing pressure that resulted in severely reduced rangeland productivity and health. There were numerous government reports outlining just how bad the situation had become. ${ }^{7}$ In Utah, there was flooding that caused portions of hillsides to flow into towns because there was no intact vegetation to hold the soil in place. The Taylor Grazing Act required that a grazing lease be tied to a parcel of private land to provide consistency over time. The federal land was administered by either the Department of Interior or the Department of Agriculture. The range wars were a thing of the past and the northern Great Basin entered into a period of relative calm.

\section{Present Day}

It seems we may have moved past the period of relative calm. There are continuing conflicts over land use, which increasingly seem to result in litigation; there are huge wildfires (Fig. 1); continued human encroachment; the spread of a host of invasive plants (and animals); and the specter of climate change effects.

It would be hard to argue that rangeland conditions have not improved from the early 1900s to the present, but concerns remain over the effects of grazing on sagebrush rangeland and associated riparian systems. With the expansion in the human population, there is much more demand for open space and recreation-so much for the earlier quote about the northern Great Basin not being habitable.

Modern human activity has an effect on the fire cycle of the region, and this change influences much about vegetation and habitat structure. The role of fire has changed in opposite directions depending on where you happen to be. At the lower elevations, there is an increase in cheatgrass (Bromus tectorum L.) and other exotic annual grasses and extensive human activity (camping, vehicle use, fireworks, trash burning, and so on) that can result in a high fire frequency. Why? Because the invasive annual grasses are very flammable, form a continuous fuel bed, and dry early in the season compared with native grasses. Invaded rangeland is ready to burn before the period of heavy summer recreation and high lightning strike activity. How much has fire frequency increased? There are areas that historically burned every 35 to 80 years, and now burn every 4 to 10 years. ${ }^{8}$ And the timing can be earlier now than it was historically. The increased fire frequency and change in timing can have very negative consequences on native vegetation. The introduction of cheatgrass in the late 1800s (it was thought to be a contaminant in wheat seed) has dramatically changed portions of the Great Basin. The really bad news is that cheatgrass appears to grow even faster as atmospheric carbon dioxide increases. ${ }^{9}$ Although there may be arguments about many aspects of climate change, there seems to be little 
disagreement that atmospheric carbon dioxide is increasing. More cheatgrass biomass further increases wildfire risk.

The fire situation is reversed on the higher elevation sites (above 5,000 feet or so). In this case, the plant communities are more productive than those at the lower elevations and have a shorter historic fire return interval-every 15 to 30 years depending on the site. However, up to this point, cheatgrass has not come to dominate these sites (although that could change). The low level of cheatgrass, removal of fuel by heavy grazing, and active fire suppression actually reduced the fire frequency during the 1900s, especially during the early to middle part of the century. One result has been a dramatic increase in woody plants, juniper species in particular. Compared with historical conditions, there probably is more woody vegetation (juniper) at the higher elevations and less woody vegetation (sagebrush) at many lower elevations, at least over significant portions of the region.

In recent years there has been tremendous focus on improving Great Basin habitat for greater sage-grouse (Centrocercus urophasianus). This sagebrush-obligate species will be evaluated for a federal endangered species listing in the near future. Current efforts are generally focused on improving habitat and applying management prescriptions such that an endangered species listing will not be deemed necessary. From my perspective, there are at least two major needs that have emerged from these efforts:

1. Improved tools and approaches for integrating science into the initial decision-making process; and

2. Better documentation of habitat responses to management treatments.

These needs arise from a general focus on accountability on two fronts - the public wants to know that sound decisions are being made, and increasingly management decisions must be explained and justified in a court of law.

The interest in accountability in rangeland management has been underway for some time. The Conservation Effects Assessment Project (CEAP) was initiated in 2003 to evaluate U.S. Department of Agriculture (USDA) conservation programs. ${ }^{10}$ This effort was broken into cropland and rangeland segments. Rangeland CEAP was a comprehensive analysis of peer-reviewed research associated with USDANatural Resources Conservation Service (NRCS) rangeland management practices. The basic conclusion of the CEAP effort was that NRCS used science in its planning process, but there was no systematic monitoring to allow ecological or socioeconomic evaluation of conservation efforts. ${ }^{10}$

In the Great Basin, as in much of the western United States, the rangeland management profession is being asked to do a better job of documenting the effects of our actions, and adjusting where necessary. Although this scrutiny can feel a little intimidating, it also provides a great opportunity. Many of the forces acting on our profession are causing regular interactions among scientists, policymakers, and land managers. There is also evidence of increasing interaction among professions, as multiple players are engaged in all the greater sage-grouse

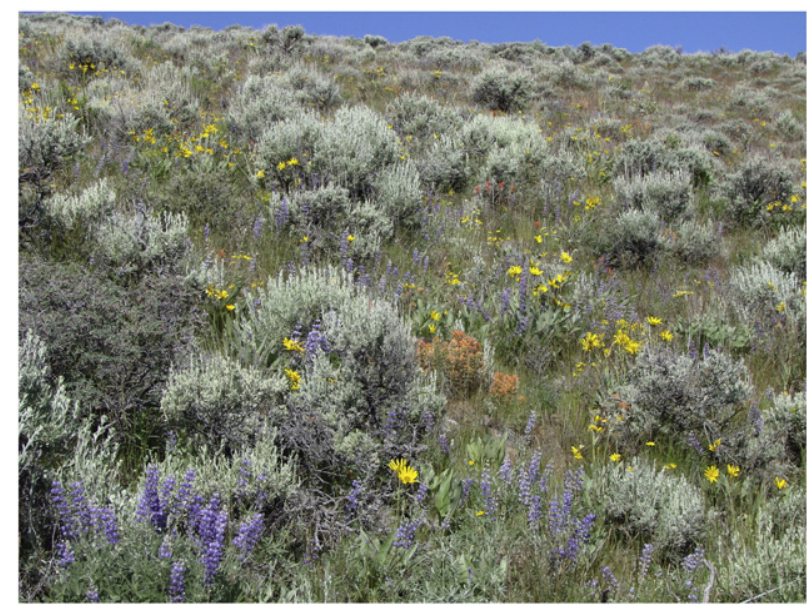

Figure 2. A diverse native sagebrush-steppe community that many folks would find appealing, and that would effectively recover from most disturbances.

planning efforts. I suggest that applied scientists spend more time evaluating how their results will be used to make decisions. In other words, field testing the application of research results and working with managers to refine the presentation of scientific concepts. There is also a clear need for simple, efficient methods to capture information on the outcomes of management/conservation efforts. There are always risks associated with broad standardization, but the more consistency there is in monitoring protocols the easier it is to aggregate data and scale up. There is a need to evaluate the success of individual practices, but also a need to aggregate multiple practices at higher spatial scales. For example, it would be nice to know how often a particular seeding treatment works; it would also be nice to know how many acres of greater sage-grouse habitat have been restored in a county or a region (by all treatments).

So, there is considerable opportunity to once again bring some tranquility to the Great Basin. One way to do that would be to get as many groups as possible working toward common goals - using sound science in management/conservation planning and evaluating the outcomes of management practices. Dealing with invasive annual grasses is no small task; we really do not have any effective large-scale solutions yet. But there are many managers, researchers, and other interested parties who are working long and hard to develop restoration tools and strategies. The complexity of the Great Basin (over both space and time) makes it unlikely that any single restoration or management practice will be uniformly successful, ${ }^{11}$ thus practices must be adjusted to fit individual situations. With dedicated folks from diverse backgrounds working toward a common cause, one has to be optimistic about a sustainable future for the northern Great Basin (Fig. 2).

\section{Acknowledgments}

The author acknowledges Drs. Chad Boyd and Kirk Davies for reviewing an earlier version of the manuscript, and two anonymous reviewers who also provided input. 


\section{References}

1. Bishop, E.M. 2003. In search of ancient Oregon: a geologic and natural history. Portland, OR, USA: Timber Press [288 pp.].

2. McAdoo, J.K., B.W. Schultz, and S.R. Swanson. 2013. Aboriginal precedent for active management of sagebrush-perennial grass communities of the Great Basin. Rangeland Ecology \& Management 66:241-253.

3. Cline, G.G. 1974. Peter Skene Odgen and the Hudson's Bay Company. Norman, OK, USA: University of Oklahoma Press [258 pp.].

4. Hines, G. 1851. Oregon: its history, conditions, and prospects. Buffalo, NY, USA: Geo. H. Derby and Co. [201 pp., see www. rootsweb.com/ ormultno/index.htm for an, online version].

5. Summary of Homestead Acts, Available at: http://en. wikipedia.org/wiki/Homesteadact (Accessed 21 August 2014).

6. Young, J.A., And B.A. Sparks. 1985. Cattle in the cold desert. Logan, UT, USA: Utah State University Press [255 pp.].

7. GRIfFiths, D. 1902. Forage conditions of the northern border of the Great Basin. Washington DC, USA: U.S. Department of Agriculture, Bureau of Plant Industry [60 pp.].

8. Whisenant, S.G. 1990. Changing fire frequencies on Idaho's Snake River Plains: ecological and management implications. In:
McArthur ED, Romney EM, Smith SD, \& Tueller PT, editors. Proceedings-symposium on cheatgrass invasion, shrub die-off, and other aspects of shrub biology and management (Tech. Rep. INT-276). Washington DC, USA: USDA-Forest Service Gen. p. 4-10.

9. Ziska, L.H., J.B. Reeves, And B. Blank. 2005. The impact of recent increases in atmospheric $\mathrm{CO} 2$ on biomass production and vegetative retention of Cheatgrass (Bromus tectorum): implications for fire disturbance. Global Change Biology 11:1325-1332.

10. Briske, D.D., L.W. Jolley, L.F. Duriancik, And J.P. DobrowOLSKI. 2011. Introduction to the conservation effects assessment project and the rangeland literature synthesis. In: \& BRISKE DD, editor. Conservation benefits of rangeland practices: assessment, recommendations, and knowledge gapes. Lawrence, KS, USA: Allen Press. p. 1-8.

11. Boyd, C.S., And T.J. SvejCAR. 2009. Managing complex problems in rangeland ecosystems. Rangeland Ecology E Management 62:491-499.

Author is Research Leader, USDA-ARS, Eastern Oregon Agricultural Research Center, Burns, OR 97720. 